DOI: 10.46340/eppd.2021.8.4.10

\title{
Yurii Olkhovskyi
}

ORCID ID: https://orcid.org/0000-0002-9777-3629

Kharkiv Regional Institute of Public Administration, Ukraine

\section{POLITICAL RESPONSIBILITY \\ IN LOCAL SELF-GOVERNMENT}

\author{
Юрій Ольховський \\ Харківський регіональний інститут Національної академії державного управління, \\ Україна
}

\section{ПОЛІТИЧНА ВІДПОВІДАЛЬНІСТЬ У МІСЦЕВОМУ САМОВРЯДУВАННІ}

The article emphasizes that the system of local self-government should pay special attention to the responsibility, as actions in this area provoke significant socio-economic consequences for an individual representative of the territorial community, the territorial community as a whole, and for society and the state. The implementation of self-governing power requires responsible, decent, competent, and professional work of officials and representative bodies of local selfgovernment. The occurrence of negative consequences as a result of the activity (or inaction) of a local government entity is one of the means to influence the affairs in the process of development of the territorial community and the life of its inhabitants. It is concluded that there are many types of responsibility in local self-government, but each one has certain features, differs in nature and procedure, its impact and method of ensuring the situation in the local community, area of application, etc. At the same time, the boundaries between the types of responsibility of representative bodies of local self-government, deputies of local councils are not clearly defined, it is possible to partially impose one type of responsibility on another, their comprehensive interaction and complementarity. There also may be some contradictions between different types of liability, due to the contradictions of norms, e.g. legal and moral norms. Such contradictions are removed through the coordination of regulators, the abolition or change of regulatory levers of influence that do not meet the requirements of social development and the development of the territorial community. Political responsibility is an effective factor in the development of local selfgovernment. Its clear enshrinement in the legal field of Ukraine will increase the efficiency of the representative body to ensure decent living conditions for residents of territorial communities. Keywords: responsibility, political responsibility, local self-government, territorial community.

Постановка проблеми. Публічне управління уособлює у собі діяльність багатьох інституцій, особистостей, які у процесі виконання покладених на них функцій приймають рішення щодо впливу на розвиток суспільства, його окремих складових. Місцеве самоврядування є вагомим сегментом функціонування суспільства, в рамках якого зосереджена значна частина інтересів конкретного громадянина. Тому рішення представницьких органів місцевого самоврядування повинні бути виважені і якомога оптимальними, що значною мірою забезпечується дієвими механізмами відповідальності в місцевому самоврядуванні.

У системі місцевого самоврядування відносинам відповідальності необхідно приділяти особливої уваги, оскільки дії у цій сфері призводять до суттєвих соціально-економічних наслідків як для окремого представника територіальної громади, територіальної громади загалом організованої в той чи інший спосіб, так і для суспільства та держави. Здійснення самоврядної влади потребує відповідальної, порядної, компетентної та професійної роботи посадових осіб та представницьких органів місцевого самоврядування. Настання негативних наслідків у результаті діяльності (чи бездіяльності) того чи іншого суб'єкта місцевого самоврядування є одним із засобів впливу у процесі розвитку територіальної громади та іiі мешканців. 
Аналіз останніх досліджень і публікацій. При дослідженні окресленої проблеми надзвичайно корисним було ознайомлення з працями сучасних вітчизняних учених, сфера наукових інтересів яких пов'язана з проблематикою відповідальності посадових осіб органів місцевого самоврядування та системи загалом. Серед них: А. Срмоленко, О. Дзьобань, О. Рубан, Р. Жмудський, Є. Бородін, Ю. Куц, Т. Тарасенко, В. Торяник та ін. Однак, більшість вказаних дослідників не ставила перед собою за мету грунтовно розглянути публічно управлінську проблематику впровадження відносин відповідальності в системі місцевого самоврядування.

Метою даної статті $є$ теоретичне обгрунтування механізмів впровадження відповідальності в системі місцевого самоврядування.

Виклад основного матеріалу. Категорія «відповідальність» як така, визначається А. Єрмоленко у Філософському енциклопедичному словнику (Київ, Інститут філософії ім. Г. С. Сковороди НАНУ, 2002 р.) як поняття, яке характеризує міру відповідності поведінки особи, групи, прошарку, держави наявним вимогам, діючим суспільним нормам, правилам співжиття, правовим законам; співвідношенням обов'язку і міри його виконання суб'єктом (особою, групою, класом). Вона виникає на основі соціальних норм і реалізується як через певні форми контролю (громадська думка, статут, закон), так і через усвідомлення суб'єктами духовно-практичної діяльності своєї суспільної ролі ${ }^{1}$.

Будь-яка відповідальність, вважають О. Дзьобань і О. Рубан є соціальною, адже є породженням суспільства і можлива лише в суспільстві. Виходячи з цього, як правило, виділяють наступні види відповідальності, по-перше, за характером відносин - соціально-економічна, правова, соціальнополітична, етична (громадянська, сімейна, матеріальна відповідальність $є$ окремими проявами зазначених видів відповідальності); по-друге, за характером суб'єкта - індивідуальна й колективна (суспільна) ${ }^{2}$.

Відповідальність у широкому сенсі в державному управлінні Р. Жмудським розуміється як: 1) зобов'язання органів державної влади і службовців виконувати поставлені завдання і функції та відповідати за результати їх виконання; 2) відносини, що забезпечують інтереси і свободу взаємопов'язаних сторін, що гарантовані суспільством і державою ${ }^{3}$.

Відповідальність можна трактувати як один із базових чинників місцевого самоврядування. Даний феномен фіксується як у міжнародних законодавчих актах, та і в національному нормативноправовому полі. Так, Всесвітня декларація місцевого самоврядування трактує його як право та обов'язок місцевих органів влади регулювати та вести громадські справи під особисту відповідальність та в інтересах місцевого населення ${ }^{4}$. У самоврядування, відповідно до якої місцеве самоврядування означає право і спроможність органів місцевого самоврядування в межах закону здійснювати регулювання та управління суттєвою часткою публічних справ, під власну відповідальність, і в інтересах місцевого населення 5 .

Конституція України питання відповідальності в системі місцевого самоврядування окреслює загалом, не регламентуючи відповідальність окремих іiї сегментів, а посилаючись на законодавство щодо ii закріплення. Так у ст. 140 щодо порядку здійснення місцевого самоврядування територіальною громадою йде посилання на відповідні законодавчі акти. Це стосується і статусу голів, депутатів і виконавчих органів ради та їхні повноваження, порядок утворення, реорганізації, ліквідації, які також визначаються законом (ст. 141), майнових відносин (ст. 143), обов'язковості виконання рішень органів місцевого самоврядування, прийнятих в межах власних повноважень, визначених законом (ст. 144). Це стосується й інших питань організації місцевого самоврядування, формування, діяльності та відповідальності органів місцевого самоврядування, які також визначаються законом (ст. 146).

\footnotetext{
${ }^{1}$ Шинкарук, В. І. (ред.) (2002). Відповідальність. Філософський енииклопедичний словник. Київ: НАН України 87. 2 Дзьобань, О. П., Рубан, О. О. (2019). Відповідальність: до проблеми концептуалізації категорії. Інформаиія і право, 4 (31), 14.

${ }^{3}$ Жмудський, Р. (2011). Політична відповідальність у державному управлінні. Збірник наукових праиь Національної академії державного управління при Президентові України, 2, 198-207, 201.

$<$ http://nbuv.gov.ua/UJRN/znpnadu_2011_2_21> (2021, липень, 21).

${ }^{4}$ Всесвітня декларація місцевого самоврядування, 1985 (Всесвітній Союз органів місцевого самоврядування). Sites.Google.Com <https://sites.google.com/site/igroupteamsite/municipalne-pravo-ukraieni/vsesvitna-deklaraciamiscevogo-samovraduvanna-1985r> (2021, липень, 21).

${ }_{5}^{5}$ Свропейська хартія місиевого самоврядування, 1985 (Рада Європи). Офіційний сайт Верховної Ради Украӥни <http://zakon3.rada.gov.ua/laws/show/994_036> (2021, липень, 21).

${ }^{6}$ Конституиія Украӥни, 1996 (Верховна Рада України).Офіційний сайт Верховної Ради Украӥни

<https://zakon.rada.gov.ua/laws/show/254\%D0\%BA/96-\%D0\%B2\%D1\%80> (2021, липень, 21).
} 
Закон України «Про місцеве самоврядування в Україні» конкретизуючи місцеве самоврядування в Україні як гарантоване державою право та реальна здатність територіальної громади - жителів села чи добровільного об'єднання у сільську громаду жителів кількох сіл, селища, міста - самостійно або під відповідальність органів та посадових осіб місцевого самоврядування вирішувати питання місцевого значення в межах Конституції i законів України закріплює формулювання «під власну відповідальність» щодо діяльності органів місцевого самоврядування $€$ спільним для міжнародних актів і українського законодавства ${ }^{1}$.

Згідно із Законом України «Про місцеве самоврядування в Україні» Відповідальність органів та посадових осіб місцевого самоврядування (Стаття 74) органи та посадові особи місцевого самоврядування несуть відповідальність за свою діяльність перед територіальною громадою, державою, юридичними і фізичними особами. Підстави, види і порядок відповідальності органів та посадових осіб місцевого самоврядування визначаються Основним Законом України та іншими законами ${ }^{2}$.

Науковці з різних позицій підходять до вивчення та тлумачення відповідальності у місцевому самоврядуванні. Є. Бородін, Т. Тарасенко - розглядають законодавчі аспекти відповідальності у місцевому самоврядуванні ${ }^{3}$; Ю. Куц - як один із аспектів знаннєвості та дієвості територіальної громади ${ }^{4}$; О. Лиска - загалом систему відповідальності у місцевому самоврядуванні ${ }^{5}$; В. Чурсін форми забезпечення відповідальності, відповідальність органів місцевого самоврядування ${ }^{6}$; Т. Тарасенко розглядає політичну відповідальність у місцевому самоврядуванні, закордонний досвід іiі здійснення ${ }^{7}$ та ін.

Необхідно зазначити, що представницькі органи місцевого самоврядування мають нести відповідальність не лише за діяльність, але і за бездіяльність. Бездіяльність - пасивна форма поведінки суб'єкта, яка виражається у не вчиненні ним тих дій, які він був зобов'язаний і міг вчинити. Це так зване невтручання у розвиток подій, яким представницький орган місцевого самоврядування повинен був запобігти або недопустити їх розвитку. У даному випадку невиконання своїх повноважень відповідною місцевою радою, слід кваліфікувати як бездіяльність. Слід зазначити, що 3 правової точки зору для визнання бездіяльності протиправною недостатньо одного лише факту неналежного та/ або несвоєчасного виконання обов'язкових дій. Важливими є також конкретні причини, умови та обставини, через які дії, що підлягали обов'язковому виконанню відповідно до закону, фактично не були виконані чи були виконані з порушенням строків. Крім того, потрібно 3'ясувати юридичний зміст, значимість, тривалість та межі протиправної бездіяльності, фактичні підстави її припинення, а також шкідливість / протиправність бездіяльності для прав та інтересів заінтересованої особи ${ }^{8}$. Тобто при неприйнятті й невиконанні окремого взятого рішення представницького органу місцевого самоврядування необхідно враховувати весь комплекс обставин такої ситуації. Багато в чому на рівні територіальної громади схожі обставини виникають саме в політичній площині й стосуються політичної відповідальності у місцевому самоврядуванні.

Політична відповідальність сама собою є багатовимірним феноменом, дослідження якого знаходиться на перетині різних галузей наукового знання - філософії, соціології, політології, юриспруденції, публічного управління тощо. Багато науковців займаються питаннями політичної

\footnotetext{
1 Закон Украӥни Про місиеве самоврядування в Україні, 1997 (Верховна Рада України).Офіційний сайт Верховної Ради України <https://zakon.rada.gov.ua/laws/show/280/97-\%D0\%B2\%D1\%80> (2021, липень, 21). 
відповідальності. Г. Малкіна визначає політичну відповідальність як вид соціальної відповідальності, що полягає у відповідності дій індивідів, соціальних та організаційних спільнот як суб'єктів політики суспільним вимогам щодо здійснення публічної влади. Вона виокремлює два основні види політичної відповідальності: морально-політичну і політико-правову ${ }^{1}$. На думку В. Торяника, політична відповідальність являє собою вид соціальної відповідальності, що полягає у застосуванні політичних санкцій до суб'єктів політики, що є порушниками політичних норм, домовленостей, узятих на себе політичних зобов'язань. Політична відповідальність може виявлятися в індивідуальній і колективній формах. Вона тісно пов'язана з поняттями історичної, моральної, юридичної відповідальності, однак відрізняється специфічним характером санкцій ${ }^{2}$.

А. Пономаренко і Д. Ковальов розглядаючи політичну відповідальність як вид соціальної відповідальності, вважають, що вона має всі характерні риси та ознаки останньої, але також має і низку особливостей та має два аспекти - позитивний і негативний. Де позитивна політична відповідальність полягає удобровільному і свідомому використанні, виконанні й дотриманні суб' єктом норм політичного життя. Така відповідальність, на думку авторів, базується на впевненості в правильності обраного політичного курсу, почуттях громадянського обов'язку і патріотизму, причетності суб'єкта до суспільно значимих доленосних рішень. Негативна політична відповідальність, на їх думку, полягає у застосуванні до порушника політичних норм різноманітних заходів впливу, створених практикою політичного життя. Така відповідальність проявляється у настанні негативних наслідків для суб'єкта політики за недотримання політико-правових норм чи неналежне виконання обов'язків (імпічмент президентові, необрання депутата, місцевої ради зокрема, чи політичної партії на наступний термін, відставка уряду, відкликання депутата місцевої ради тощо). Негативна відповідальність вважається ретроспективною, тобто відповідальністю суб'єкта за свої дії в минулому³.

У публічному управлінні політична відповідальність постає як відповідальність за цільове здійснення політичного представництва, вважає В. Мельниченко ${ }^{4}$

Необхідно відмітити, що рівень політичної відповідальності суб'єктів влади і управління виступає чи не найголовнішим критерієм і виміром ступеня демократичності політичної системи і рівня розвитку громадянського суспільства. Політична відповідальність докорінним чином відрізняється від юридичної відповідальності ${ }^{5}$.

Політична відповідальність у місцевому самоврядуванні є складним явищем, дослідженням якого займаються науковці різних галузей знань. Так, вивчаючи політичну відповідальність у системі місцевого самоврядування В. Куйбіда $\mathrm{i}$ Л. Смолова трактують це поняття як покладені на представницькі органи місцевого самоврядування територіальною громадою відповідно до закону обов'язки ефективно управляти іï власністю, надавати якісні управлінські й соціальні послуги, виконувати взяті на себе передвиборчі зобов'язання та обіцянки, відстоювати іiі інтереси перед державою, у разі невиконання яких для представницьких органів місцевого самоврядування настають негативні наслідки, спричинені юридично оформленими діями територіальної громади ${ }^{6}$.

Виходячи з того, що розкриття політичної відповідальності має реалізовуватися через виокремлення трьох іiі вимірів: інформаційного, аргументованого і санкційного ${ }^{7}$, де інформаційний вимір стосується транспарентності публічної влади (відкритості й прозорості щодо підготовки,

\footnotetext{
${ }^{1}$ Малкіна, Г. (2010). Демократія і політична відповідальність. Сучасна украӥнська політика. Політики $i$ політологи про неї, 21, 24.

2 Торяник, В. М. (2006). Взаємна політична відповідальність державної влади і громадянина в сучасній правовій державі: автореферат дисертаиії на здобуття наукового ступеня кандидата політичних наук. Дніпропетровськ: Дніпропетровський національний університет.

${ }^{3}$ Пономаренко, А. Б., Ковальов, Д. В. (2019). Політична відповідальність народу. Політичне життя, 1, $31-36$.

${ }^{4}$ Мельниченко, В. (2011). Політична відповідальність публічно-владних інституцій у системі соціальної відповідальності. Вісник НАДУ, 1, 175-183. <http://nbuv.gov.ua/UJRN/Vnadu_2011_1_25> (2021, липень, 21).

${ }^{5}$ Ребкал, В. А., Шахов, В. А. (ред.) (2011). Політична відповідальність державно-управлінської еліти як чинник підвищення ефективності державного управління. Київ: НАДУ, 5.

${ }^{6}$ Куйбіда, В. (2015). Відповідальність представницьких органів місцевого самоврядування перед

територіальними громадами: практичні аспекти реалізації. Регіональне управління та місцеве самоврядування: збірник наукових пращь, 1, 160.

${ }^{7}$ Голинська, Х. (2010). Партійно-політична відповідальність: зарубіжний та український досвід: aвтореферат дисертації на здобуття наукового ступеня кандидата політичних наук. Київ: Київський Національний Університет ім. Т. Шевченка.
} 
прийняття й виконання рішень представницькими органами місцевого самоврядування, діяльності депутатського корпусу місцевих рад, створення системи та умов для комунікації між органами місцевого самоврядування, депутатами місцевих рад і мешканцями територіальної громади, можливості та механізми залучення громадськості до вироблення й виконання рішень відповідних місцевих рад тощо. Аргументований вимір полягає в чіткому обгрунтуванні рішення та дій представницьких органів місцевого самоврядування та депутатського корпусу місцевих рад, який базується на нормативноправових та наукових засадах, застосовуючи також моральні та прецедентні принципи. Санкційний полягає в чіткому механізмі адміністрування застосування відповідальності за ті чи інші дії (або бездіяльність), які призводять до негативних наслідків в життєдіяльності територіальної громади (або окремих мешканців) та невиконанні передвиборчих програм або обіцянок.

Розкриття цих вимірів політичної відповідальності у місцевому самоврядуванні дозволить, на думку Т. Тарасенко, більш повно визначити основи утвердження інституту політичної відповідальності в системі місцевого самоврядування ${ }^{1}$.

Одним із санкційних вимірів відповідальності у місцевому самоврядуванні $є$ дострокове припинення повноважень місцевої ради, який зафіксовано у ст. 78 базового Закону щодо розвитку місцевого самоврядування в Україні. Такі випадки можуть бути: якщо рада прийняла рішення 3 порушенням Конституції України, вказаного та інших законів, прав і свобод громадян, ігноруючи при цьому вимоги компетентних органів про приведенні цих рішень відповідно до закону; якщо сесії ради не проводяться без поважних причин у строки, встановлені законодавством, або рада не вирішує питань, віднесених до її відання, а також передбачених законами України «Про військово-цивільні адміністрації» ${ }^{2}$, «Про правовий режим воєнного стану» ${ }^{3}$. Припинення повноважень місцевої ради може відбутися за рішенням місцевого референдуму, порядок проведення якого щодо дострокового припинення повноважень ради визначається законом про місцеві референдуми ${ }^{4}$.

В. Куйбіда і Л. Смолова пропонують цілком слушно розширити коло питань щодо дострокового припинення повноважень місцевої ради, вважаючи за доцільне встановити такі підстави для настання відповідальності представницьких органів місцевого самоврядування перед громадами: 1) незабезпечення здійснення наданих законом повноважень; 2) неефективне вирішення місцевих справ; 3) розбіжність дій представницьких органів місцевого самоврядування з очікуваннями і вимогами громади; 4) невідповідність діяльності представлених у раді політичних сил, які у ній становлять більшість, раніше заявленому політичному курсу ${ }^{5}$. Пункт «4» (а саме «невідповідність діяльності представлених у раді політичних сил, які у ній становлять більшість, раніше заявленому політичному курсу») пропонуємо доповнити позицією щодо невиконання політично задекларованих перевиборчих програм та обіцянок кандидатів у депутати місцевої ради. Що, по-перше, підвищить відповідальність представницького корпусу, по-друге, може бути підставою для здійснення санкційних процедур щодо відкликання депутата місцевої ради.

Висновки $з$ даного дослідження і перспективи подальших розвідок у даному напрямку. Таким чином, відповідальність у місцевому самоврядуванні налічує багато видів, але кожен із них має певні особливості, відрізняється характером та порядком реалізації, їх впливом та способом забезпечення на ситуацію в територіальній громаді, сферою дії та ін. При цьому межі між видами відповідальності представницьких органів місцевого самоврядування, депутатським корпусом місцевих рад не є чітко окресленими, цілком можливе часткове накладання одного виду відповідальності на інший, їх комплексна взаємодія та взаємодоповнення. Водночас між різними видами відповідальності можуть виникати окремі протиріччя, що обумовлено суперечностями норм, скажімо, нормативно-правових та моральних норм. Подібні протиріччя знімаються через узгодження

\footnotetext{
${ }^{1}$ Тарасенко, Т. (2017). Політична відповідальність у місцевому самоврядуванні: зміст та актуальні аспекти дослідження. Державне управління та місиеве самоврядування, 1 (32), 160.

2 Закон України Про військово-цивільні адміністрації, 2015 (Верховна Рада України). Офіційний сайт Верховної Ради Украӥни <https://zakon.rada.gov.ua/laws/show/141-19> (2021, липень, 21).

3 Закон України Про правовий режим воєнного стану, 2015 (Верховна Рада України). Офіиійний сайт Верховної Ради Украӥни <https://zakon.rada.gov.ua/laws/show/389-19> (2021, липень, 21).

4 Закон Украӥни Про місиеве самоврядування в Україні, 1997 (Верховна Рада України). Офіційний сайт Верховної Ради Украӥни <https://zakon.rada.gov.ua/laws/show/280/97-\%D0\%B2\%D1\%80> (2021, липень, 21). ${ }^{5}$ Куйбіда, В. (2015). Відповідальність представницьких органів місцевого самоврядування перед територіальними громадами: практичні аспекти реалізації. Регіональне управління та місиеве самоврядування: збірник наукових праць НАДУ, 1, 153.
} 
регуляторів, скасування чи зміни нормативно-правових важелів впливу, які не відповідають вимогам суспільного розвитку та розвитку територіальної громади.

Політична відповідальність $є$ дієвим чинником розвитку місцевого самоврядування. Ïї чітке закріплення в нормативно-правовому полі України дасть можливість підвищити ефективність діяльності представницького органу щодо забезпечення гідних умов проживання мешканців територіальних громад.

\section{References:}

1. Borodin, Ye. I., Tarasenko, T. M. (2017). Vyznachennya vidpovidalnosti v mistsevomu samovryaduvanni v Ukrayini: zakonodavchyy aspekt [Definition of responsibility in local self-government in Ukraine: legislative aspect]. Aspekty publichnoho upravlinnya [Aspects of public administration], 5 (8-9), 56-65. <https://aspects.org.ua/index.php/journal/article/view/341/343> (2021, July, 21). [in Ukrainian].

2. Vsesvitnya deklaratsiya mistsevoho samovryaduvannya, 1985 (Vsesvitniy Soyuz orhaniv mistsevoho samovryaduvannya) [World Declaration of Local Self-Government, 1985 (World Union of Local Governments)]. Sites.Google.Com <https://sites.google.com/site/igroupteamsite/municipalne-pravo-ukraieni/vsesvitna-deklaraciamiscevogo-samovraduvanna-1985r> (2021, July, 21). [in Ukrainian].

3. Golinska, H. (2010). Partiyno-politychna vidpovidalnist: zarubizhnyy ta ukrayinskyy dosvid [Party-political responsibility: foreign and Ukrainian experience]: avtoreferat dysertatsiyi na zdobuttya naukovoho stupenya kandydata politychnykh nauk [dissertation abstract for the degree of candidate of political science].

Kyiv: Kyiv National University named after T. Shevchenko. [in Ukrainian].

4. Dzjoban, O. P., Ruban, O. O. (2019). Vidpovidalnist: do problemy kontseptualizatsiyi katehoriyi [Responsibility: to the problem of conceptualization of the category]. Informatsiya i pravo [Information and law], 4 (31), 14. [in Ukrainian].

5. Yevropeyska khartiya mistsevoho samovryaduvannya, 1985 (Rada Yevropy) [European Charter of Local Self-Government, 1985 (Council of Europe)]. Ofitsiynyy sayt Verkhovnoyi Rady Ukrayiny [Official site of the Verkhovna Rada of Ukraine] <http://zakon3.rada.gov.ua/laws/show/994_036> (2021, July, 21). [in Ukrainian].

6. Zhmudsky, R. (2011). Politychna vidpovidalnist u derzhavnomu upravlinni [Political responsibility in public administration]. Zbirnyk naukovykh prats Natsionalnoyi akademiyi derzhavnoho upravlinnya pry Prezydentovi Ukrayiny [Collection of scientific works of the National Academy of Public Administration under the President of Ukraine], 2, 198-207. <http://nbuv.gov.ua/UJRN/znpnadu_2011_2_21> (2021, July, 21). [in Ukrainian].

7. Zakon Ukrayiny Pro viyskovo-tsyvilni administratsiyi, 2015 (Verkhovna Rada Ukrayiny) [Law of Ukraine on Military-Civil Administrations, 2015 (Verkhovna Rada of Ukraine)]. Ofitsiynyy sayt Verkhovnoyi Rady Ukrayiny [Official site of the Verkhovna Rada of Ukraine] <https://zakon.rada.gov.ua/laws/show/141-19> (2021, July, 21). [in Ukrainian].

8. Zakon Ukrayiny Pro mistseve samovryaduvannya v Ukrayini, 1997 (Verkhovna Rada Ukrayiny) [Law of Ukraine on Local Self-Government in Ukraine, 1997 (Verkhovna Rada of Ukraine)]. Ofitsiynyy sayt Verkhovnoyi Rady Ukrayiny [Official site of the Verkhovna Rada of Ukraine] 〈https://zakon.rada.gov.ua/laws/show/280/97-вp\#Text> (2021, July, 21). [in Ukrainian].

9. Zakon Ukrayiny Pro pravovyy rezhym voyennoho stanu, 2015 (Verkhovna Rada Ukrayiny) [Law of Ukraine On the Legal Regime of Martial Law, 2015 (Verkhovna Rada of Ukraine)]. Ofitsiynyy sayt Verkhovnoyi Rady Ukrayiny [Official site of the Verkhovna Rada of Ukraine] <https://zakon.rada.gov.ua/laws/show/389-19> (2021, July, 21). [in Ukrainian].

10. Konstytutsiya Ukrayiny, 1996 (Verkhovna Rada Ukrayiny) [Constitution of Ukraine, 1996 (Verkhovna Rada of Ukraine)]. Ofitsiynyy sayt Verkhovnoyi Rady Ukrayiny [Official site of the Verkhovna Rada of Ukraine] <https://zakon.rada.gov.ua/laws/show/254\%D0\%BA/96-\%D0\%B2\%D1\%80> (2021, July, 21). [in Ukrainian].

11. Kuybida, V. (2015). Vidpovidalnist predstavnytskykh orhaniv mistsevoho samovryaduvannya pered terytorialnymy hromadamy: praktychni aspekty realizatsiyi [Responsibility of representative bodies of local selfgovernment before territorial communities: practical aspects of implementation]. Rehionalne upravlinnya ta mistseve samovryaduvannya: zbirnyk naukovykh prats [Regional management and local self-government: a collection of scientific works], $1,146-163$. [in Ukrainian].

12. Kuts, Yu. O. (ed.) (2011). Terytorialna hromada: znannyevist, diyevist [Territorial community: knowledge, effectiveness]. Kharkiv: Master.

13. Lyska, O. H. (2010). Systema vidpovidalnosti u mistsevomu samovryaduvanni [The system of responsibility in local self-government]. Humanitarnyy visnyk Zaporizkoyi derzhavnoyi inzhenernoyi akademiyi [Humanitarian Bulletin of the Zaporizhia State Engineering Academy], 43, 75-82 <http:// www.zgia.zp.ua/gazeta/VISNIK_43_9.pdf> (2021, July, 21). [in Ukrainian].

14. Malkina, H. (2010). Demokratiya i politychna vidpovidalnist. [Democracy and political responsibility]. Suchasna ukrayinska polityka. Polityky i politolohy pro neyi [Modern Ukrainian politics. Politicians and political scientists about her], 21, 23-32. [in Ukrainian]. 
15. Melnychenko, V. (2011). Politychna vidpovidalnist publichno-vladnykh instytutsiy u systemi sotsialnoyi vidpovidalnosti [Political responsibility of public institutions in the system of social responsibility]. Visnyk NADU [NAPA Bulletin], 1, 175-183. <http://nbuv.gov.ua/UJRN/Vnadu_2011_1_25> (2021, July, 21). [in Ukrainian].

16. Ponomarenko, A. B., Kovalov, D. V. (2019). Politychna vidpovidalnist narodu [Political responsibility of the people]. Politychne zhyttya [Political life], 1, 31-36. [in Ukrainian].

17. Postanova № 342/158/17 vid 17 kvitnya 2019 (Verkhovnyy Sud Ukrayiny) [Resolution № 342/158/17 of April 17, 2019 (Supreme Court of Ukraine)]. Ligazakon <https://ips.ligazakon.net/document/C008313> (2021, July, 21). [in Ukrainian].

18. Rebkal, V. A., Shakhov, V. A. (ed.) (2011). Politychna vidpovidalnist derzhavno-upravlinskoyi elity yak chynnyk pidvyshchennya efektyvnosti derzhavnoho upravlinnya [Political responsibility of the public administration elite as a factor in improving the efficiency of public administration]. Kyiv: NADU. [in Ukrainian].

19. Tarasenko, T. (2017). Politychna vidpovidalnist v mistsevomu samovryaduvannya: zmist ta aktualni aspekty doslidzhennya [Political responsibility in local self-government: content and current aspects of the study]. Derzhavne upravlinnya ta mistseve samovryaduvannya [Public administration and local self-government], 1 (32), 158-162. [in Ukrainian].

20. Tarasenko, T. (2019). Politychna vidpovidalnist u systemi mistsevoho samovryaduvannya: dosvid krayin Baltiyi [Political responsibility in the system of local self-government: the experience of the Baltic States]. Publichne administruvannya: teoriya ta praktyka [Public administration: theory and practice], 1 (21), 1-18. [in Ukrainian].

21. Toryanik, V. M. (2006). Vzayemna politychna vidpovidal'nist' derzhavnoyi vlady i hromadyanyna v suchasniy pravoviy derzhavi [Mutual political responsibility of the state power and the citizen in the modern state governed by the rule of law]: avtoreferat dysertatsiyi na zdobuttya naukovoho stupenya kandydata politychnykh nauk [the dissertation author's abstract on competition of a scientific degree of the candidate of political sciences]. Dnipropetrovsk: Dnipropetrovsk National University. [in Ukrainian].

22. Chursin, V. P. (2011). Formy zabezpechennya vidpovidalnosti orhaniv mistsevoho samovryaduvannya [Forms of ensuring the responsibility of local governments]. Naukovyy visnyk Akademiyi munitsypalnoho upravlinnya [Scientific Bulletin of the Academy of Municipal Administration], 2, 384-391. [in Ukrainian].

23. Shinkaruk, V. I. (ed.) (2002). Responsibility. Philosophical encyclopedic dictionary [Responsibility. Philosophical encyclopedic dictionary]. Kyiv: National Academy of Sciences of Ukraine. [in Ukrainian]. 